\title{
ANALISIS TINGKAT PENGETAHUAN REMAJA TENTANG PERILAKU MEROKOK DI KOTA AMBON
}

\author{
Eunike M. Sahetapy ${ }^{1}$, Yopi A. Lesnussa ${ }^{2}$, Venn Y. I. Ilwaru ${ }^{3}$ \\ 1,2 Jurusan Matematika FMIPA, Universitas Pattimura \\ Jl. Ir. M. Putuhena, Kampus Unpatti, Poka-Ambon, Indonesia \\ e-mail: ${ }^{2}$ yopi_a_lesnussa@yahoo.com
}

\begin{abstract}
Abstrak
Pemandangan orang merokok dapat kita temui di dalam kendaraan umum, kantor, pasar, atau tempat umum lainnya, bahkan dalam keluarga sendiri. Pada umumnya seseorang mulai merokok sejak usia remaja. Jumlah perokok laki-laki jauh lebih tinggi dibandingkan perempuan dimana jika diuraikan menurut umur, prevalensi perokok laki-laki paling tinggi pada umur 15-19 tahun. Berdasarkan permasalahan tersebut, dilakukan penelitian untuk mengetahui pengaruh antara usia, status merokok orang tua, komunikasi dengan orang tua, komunikasi dengan teman sepergaulan, pengetahuan tentang merokok, perokok aktif dan pasif, akses media informasi, dan intensitas melihat iklan rokok dengan tingkat pengetahuan remaja tentang perilaku merokok kemudian melihat model tingkat pengetahuan remaja tentang perilaku merokok dengan menggunakan Model Regresi Logistik Ordinal dan juga untuk mengetahui variabel yang berpengaruh signifikan terhadap tingkat pengetahuan remaja tentang perilaku merokok di Kota Ambon. Dari data yang diperoleh maka dapat disimpulkan bahwa variabel yang berpengaruh signifikan terhadap tingkat pengetahuan remaja tentang perilaku merokok adalah variabel $x_{1}$ (Pengetahuan remaja tentang merokok terhadap kesehatan), $\mathrm{x}_{4}$ (Pengetahuan tentang perokok pasif), $\quad \mathrm{x}_{5}$ (Pengetahuan tentang perbedaan antara Perokok Pasif dan perokok Aktif), $\mathrm{x}_{6}$ (Larangan merokok), $\mathrm{x}_{8}$ (Komunikasi dengan orang tua) $\mathrm{x}_{9}$ (Komunikasi dengan teman pergaulan), $\mathrm{x}_{10}$ (Status merokok orang tua).
\end{abstract}

Kata Kunci: Perilaku merokok, regresi logistik ordinal.

\section{THE ANALYSIS OF ADOLESCENT KNOWLEDGE LEVEL ABOUT SMOKING BEHAVIOR IN AMBON}

\begin{abstract}
Views of the smokers can be met in public transportation, offices, markets, or other public places, even in our family. In general, a person starts smoking since teenagers. The number of male smokers is higher than of female, for which, if broken down by age, the prevalence of male smokers was highest in the age of 1519 years. Based on these problems, our research is to determine the effect of age, parents smoking status, communication with parents, communication with friends, knowledge about smoking, active and passive smokers, media access information, and the intensity of seeing cigarette ads with teenager level of knowledge about smoking behavior then look at the model level of knowledge about teenage smoking behavior using Ordinal Logistic Regression Model and also to determine the variables that significantly influence the level of knowledge about teenagers smoking behavior in the city of Ambon. From the data, it can be concluded that the variables that significantly influence the level of knowledge about teenage smoking behavior is variable $x_{1}$ (Teenager knowledge about smoking toward health), $x_{4}$ (Knowledge of passive smokers), $x_{5}$ (Knowledge of the difference between passive smokers and active smokers), $x_{6}$ (smoking warning), $x_{8}$ (Communication with parents) $x_{9}$ (Communication with friends), $x_{10}$ (smoking status of parents).
\end{abstract}

Keywords: Ordinal logistic regression, smoking behavior. 


\section{Pendahuluan}

Dalam kehidupan sehari-hari, seringkali kita menemui orang-orang yang merokok di dalam kendaraan umum, kantor, pasar, atau tempat umum lainnya, bahkan dalam keluarga sendiri. Pada umumnya seseorang mulai merokok sejak usia remaja. Sejumlah studi menemukan penghisapan rokok pertama dimulai saat usia 11-13 tahun [1]. Perilaku merokok diawali oleh rasa ingin tahu dan pengaruh teman sebaya. Modelling (meniru perilaku orang lain) menjadi salah satu faktor dalam memulai perilaku merokok. Perilaku merokok pada remaja umumnya semakin lama akan semakin meningkat sesuai dengan tahap perkembangannya yang ditandai dengan meningkatnya frekuensi dan intensitas merokok, dan sering mengakibatkan mereka ketergantungan nikotin (Laventhal dan Cleary dalam Mc Gee, 2005). Jumlah perokok laki-laki jauh lebih tinggi dibandingkan perempuan dimana jika diuraikan menurut umur, prevalensi perokok laki-laki paling tinggi pada umur 15-19 tahun. Yayasan Kanker Indonesia (YKI) menemukan 27,1\% dari 1961 responden pelajar pria SMA/SMK, sudah mulai atau bahkan terbiasa merokok. Umumnya siswa kelas satu menghisap satu sampai empat batang perhari, sementara siswa kelas tiga mengonsumsi rokok lebih dari sepuluh batang perhari.

Para ahli kesehatan menyatakan bahwa merokok merupakan perilaku yang berbahaya, karena dapat menimbulkan berbagai macam penyakit. Bahkan pada bungkus rokok sudah terdapat seruan bahwa merokok dapat merugikan kesehatan seperti dapat menyebabkan kanker, impotensi, jantung, gangguan kehamilan dan janin. Rokok mengandung zat-zat yang berbahaya bagi kesehatan diantaranya tar, nikotin (menyebabkan kecanduan/ketergantungan), karbonmonoksida (mampu mengikat Hb/hemoglobin dalam darah), kadmium, akrolein, amoniak, asam format, hidrogensianida, fenol, formaldehid, nitrous oxid, aseltol, hidrogensulfida, piridin, metilklorida, dan metanol.

Berdasarkan permasalahan tersebut, maka penulisan ini dilakukan untuk mengetahui pengaruh antara usia, tingkat pendidikan orang tua, status merokok orang tua, komunikasi dengan ayah, komunikasi dengan ibu, teman sepergaulan, akses media informasi dan intensitas melihat iklan rokok dengan tingkat pengetahuan remaja tentang perilaku merokok kemudian melihat model tingkat pengetahuan remaja tentang perilaku merokok dengan menggunakan Model Regresi Logistik Ordinal dan juga untuk mengetahui variabel yang berpengaruh signifikan terhadap tingkat pengetahuan remaja tentang perilaku merokok di Kota Ambon.

\section{Tinjauan Pustaka}

\subsection{Uji Statistik}

\section{a. Uji Validitas}

Validitas dalam bahasa sederhana digunakan untuk mengukur sah atau valid tidaknya suatu kuesioner untuk mengungkapkan sesuatu yang akan diukur.

Validitas dapat diuji dengan beberapa cara, diantaranya:

i. Melakukan korelasi bivariat antar masing-masing skor dengan total skor variabel.

ii. Membandingkan nilai $r$ hitung dengan $r$ table.

iii. Conformatory Factor Analysis (CFA).

\section{b. Uji Reliabilitas}

Reliabilitas secara sederhana adalah alat untuk menguji konsistensi dari waktu ke waktu. Lazimnya dilakukan dengan One Shot atau pengukuran sekali saja, dimana bila dengan SPSS diuji melalui cronbach alpha (Uji validitas cara ke-2) dengan ketentuan bila nilai cronbach alpha $>0$, maka variabel tersebut reliabel.

\subsection{Analisis Regresi Logistik Ordinal}

Analisis regresi logistik ordinal merupakan salah satu metode statistik yang menggambarkan hubungan antara suatu variabel respon $(Y)$ dengan lebih dari satu variabel prediktor $(X)$ dimana variabel respon lebih dari dua kategori dan skala pengukuran bersifat tingkatan (Hosmer dan Lemeshow, 2000).

Model regresi logistik adalah sebagai berikut.

$$
\pi(x)=\frac{e^{g(x)}}{1+e^{g(x)}}
$$


Peluang kumulatif didefinisikan sebagai berikut.

$$
P\left(Y \leq j \mid x_{i}\right)=\frac{\exp \left(\alpha_{j}+\sum_{k=1}^{p} \beta_{k} x_{i k}\right)}{1+\exp \left(\alpha_{j}+\sum_{k=1}^{p} \beta_{k} x_{i k}\right)}
$$

dengan, $i=1,2,3, \ldots, n$.

Berikut fungsi distribusi logistik umum

$$
F(x)=\frac{1}{1+e^{-x}}=\frac{e^{x}}{1+e^{x}}
$$

Cummulative logit models didapatkan dengan membandingkan peluang kumulatif yaitu peluang kurang dari atau sama dengan kategori respon ke- $j$ pada $p$ variabel prediktor yang dinyatakan dalam vektor $x_{i}$. Berikut formulasi cumulative logit models

$$
\operatorname{Logit} P\left(Y \leq j x_{i}\right)=\log \left(\frac{P\left(Y \leq j \mid x_{i}\right)}{P\left(Y>j \mid x_{i}\right)}\right)
$$

Jika terdapat kategori respon dimana $\mathrm{j}=0,1,2$ maka nilai peluang untuk tiap kategori respon sebagai berikut:

$$
\begin{aligned}
& \phi_{1}(x)=\frac{e^{g_{1}(x)}}{1+e^{g_{1}(x)}} \\
& \phi_{2}(x)=\frac{e^{g_{2}(x)}-e^{g_{1}(x)}}{\left(1+e^{g_{2}(x)}\right)\left(1+e^{g_{1}(x)}\right)} \\
& \phi_{o}(x)=1-\phi_{1}(x)-\phi_{2}(x)=\frac{1}{\left(1+e^{g_{2}(x)}\right)}
\end{aligned}
$$

Model Proposional pada kejadian $Y \leq j$ untuk $x=x_{1}$ dan $x=x_{2}$ adalah

$$
\frac{P\left(Y \leq j \mid x_{1}\right) / P\left(Y>j \mid x_{1}\right)}{P\left(Y \leq j \mid x_{2}\right) / P\left(Y>j \mid x_{2}\right)}=\frac{\exp \left(\beta_{0 j}+x_{1}{ }^{\prime} \beta\right)}{\exp \left(\beta_{0 j}+x_{2}{ }^{\prime} \beta\right)}=\exp \left(x_{1}-x_{2}\right.
$$

Metode kemungkinan nilai maksimum (Maximum Likelihood Estimator) merupakan metode yang digunakan untuk menaksir parameter-parameter model regresi logistik dengan dengan memberikan nilai estimasi $\beta$ dengan memaksimumkan fungsi Likelihood (Agresti, 2002).

Berikut fungsi Likelihood untuk sampel dengan $n$ sampel random

$$
l(\beta)=\prod_{i=1}^{n}\left[\phi_{o}\left(x_{i}\right)^{y_{0 i}} \phi_{1}\left(x_{i}\right)^{y_{1 i}} \phi_{2}\left(x_{i}\right)^{\left.y_{2 i}\right]}\right.
$$

dengan $i=1,2, \cdots, J$.

Dari persamaan di atas didapatkan fungsi ln-Likelihood sebagai berikut

$$
L(\beta)=\sum_{i=1}^{N} y_{0 i} \ln \left[\phi_{o}\left(x_{i}\right)\right]+y_{1 i} \ln \left[\phi_{1}\left(x_{i}\right)\right]+y_{2 i} \ln \left[\phi_{2}\left(x_{i}\right)\right]
$$

Maksimum ln-Likelihood diperoleh dengan mendeferensialkan $L(\beta)$ terhadap $\beta$ dan menyamakan dengan nol. Maximum Likelihood Estimator (MLE) merupakan metode untuk mengestimasi varians dan kovariansi dari taksiran $\beta$ yang diperoleh dari turunan kedua fungsi ln-Likelihood. Untuk mendapatkan nilai tersebut digunakan metode iterasi Newton Raphson (Agresti, 2002). Formulasi iterasi Newton Raphson adalah

$$
\beta^{(t+1)}=\beta^{(t)}-\left(H^{(t)}\right)^{-1} q^{t}
$$

Menurut Hosmer dan Lameshow (1989), model yang telah diperoleh perlu diuji kesignifikasiannya, dengan melakukan pengujian statistik. Pengujian yang dilakukan adalah

\section{a. Uji Serentak}

Uji serentak dilakukan untuk memeriksa keberartian koefisien $\beta$ secara keseluruhan. 
Hipotesis:

$$
\begin{aligned}
& H_{0}: \beta_{1}=\beta_{2}=\cdots=\beta_{j}=0 \\
& H_{1}: \text { Minimal ada satu } \beta_{j} \neq 0, j=1,2, \cdots, p
\end{aligned}
$$

Statistik Uji:

$$
G=-2 \log \left[\frac{\left(\frac{n_{0}}{n}\right)^{n_{0}}\left(\frac{n_{1}}{n}\right)^{n_{1}}\left(\frac{n_{2}}{n}\right)^{n_{2}}}{\prod_{i=1}^{n}\left[\phi_{o}\left(x_{i}\right)^{y_{0 i}} \phi_{1}\left(x_{i}\right)^{y_{1 i}} \phi_{2}\left(x_{i}\right)^{y_{2 i}}\right]}\right]
$$

dimana,

$$
n_{0}=\sum_{i=1}^{n} y_{0 i}, n_{1}=\sum_{i=1}^{n} y_{1 i}, n_{2}=\sum_{i=1}^{n} y_{2 i}
$$

dan $n=n_{0}+n_{1}+n_{2}$

Keterangan:

$n_{0}$ : banyaknya nilai observasi yang $Y=0$

$n_{1}$ : banyaknya nilai observasi yang $Y=1$

$n_{2}$ : banyaknya nilai observasi yang $Y=2$

$n$ : banyaknya observasi

$H_{0}$ ditolak pada tingkat signifikan sebesar $\alpha$ bila nilai $p$-value $<\alpha$ atau nilai $G>X^{2}{ }_{\alpha, d b}$

\section{b. Uji Parsial}

Uji parsial digunakan untuk memeriksa kemaknaan koefisien $\beta$ secara individu.

Hipotesis :

$H_{0}: \beta_{j}=0, j=1,2, \ldots, p$

$H_{1}: \beta_{j} \neq 0$

Statistik Uji :

$$
W_{j}=\frac{\hat{\beta}_{j}}{S \hat{E}\left(\hat{\beta}_{j}\right)} \sim N(0,1)
$$

$H_{0}$ ditolak apabila $\left|W_{j}\right|>Z_{\alpha / 2}$ atau nilai $p$-value $<\alpha$, dimana $\mathrm{Z}$ menunjukkan nilai variabel random pada tabel distribusi normal standar.

Menurut Hosmer dan Lameshow (1989), terdapat statistik uji yang digunakan untuk menguji kesesuaian model regresi logistik adalah Goodness of Fit dengan hipotesis sebagai berikut.

$H_{0}$ : Model cukup memenuhi

$H_{1}$ : Model tidak memenuhi

Statistik Uji:

$$
X^{2}=\sum_{j=1}^{J} \frac{\left(y_{j}-m_{j} \phi_{j}\right)^{2}}{m_{j} \phi_{j}\left(1-\phi_{j}\right)}
$$

dengan, $j=1,2,3, \ldots, J$ 
dimana $y_{j}=$ variabel respon ke- $j$

$$
\begin{aligned}
& m_{j}=\text { banyaknya observasi yang memiliki nilai } \phi_{j} \\
& \phi_{j}=\text { peluang kumulatif }
\end{aligned}
$$

Daerah kritis: Tolak $H_{0}$ jika $X^{2}{ }_{\text {hitung }}>X^{2}{ }_{(J-2)}$

Menurut Walpole (1995), uji independensi dilakukan untuk mengetahui ada atau tidaknya hubungan antara variabel respon dengan variabel prediktor. Pengujian tersebut dilakukan dengan menggunakan uji Chi-square.

Hipotesis:

dengan variabel respon

Statistik Uji:

$$
X^{2}=\sum_{i j=1}^{r k} \frac{\left(o_{i j}-e_{i j}\right)^{2}}{e_{i j}}
$$

dimana,

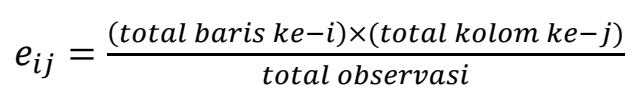

Keterangan;

$$
\begin{aligned}
& r=\text { banyaknya baris } \\
& k=\text { banyaknya kolom } \\
& o_{i j}=\text { frekuensi observasii baris ke-i kolom ke-j } \\
& e_{i j}=\text { frekuensi harapan baris ke-i kolom ke-j } \\
& d b=\text { derajat bebas }=(r-1)(k-1)
\end{aligned}
$$

Daerah kritis: Tolak $\mathrm{H}_{0}$ jika $X^{2}{ }_{\text {hitung }}>X^{2}{ }_{(d b, \alpha)}$

\section{Hasil dan Pembahasan}

\subsection{Data Tingkat Pengetahuan Remaja tentang Perilaku Merokok}

Perilaku merokok merupakan perilaku yang berbahaya bagi kesehatan, tetapi masih banyak yang melakukannya. Bahkan orang mulai merokok ketika mereka masih remaja. Sejumlah studi menegaskan bahwa kebanyakan perokok merokok antara umur 11 dan 13 tahun dan $85 \%$ sampai 95\% sebelum umur 18 tahun (Laventhal dan Dhuyvettere dalam [1]).

Rokok adalah benda beracun yang berbahaya bagi kesehatan, karena terdapat 4000 bahan kimia dengan 3 komponen utama yaitu nikotin, tar dan karbonmonoksida. Kebiasaan remaja yang sulit dihindari ialah merokok. Kemajuan ilmu pengetahuan seharusnya meningkatkan kesadaran remaja untuk tidak merokok. Namun pada kenyataannya banyak remaja yang terbiasa merokok. Dengan adanya pengetahuan yang baik tentunya juga akan berdampak pada sikap yang positif, begitu pula sebaliknya.

Untuk menunjang penulisan ini penulis mengambil sampel sebanyak 30 responden yang diberi kuesioner untuk memberikan peringkat penilaian. Peringkat yang diberikan dari satu sampai lima. Peringkat satu diberikan apabila responden memilih pilihan yang salah atau memilih pilihan "sangat buruk" sedangkan peringkat lima diberikan untuk responden memilih pilihan yang benar atau memilih pilihan "sangat baik". Penelitian ini menggunakan 11 variabel yaitu:

$x_{1}$ : Pengetahuan remaja tentang merokok terhadap kesehatan

$x_{2}$ : Kerugian merokok

$x_{3}$ : Istilah perokok pasif 
$x_{4}$ : Pengetahuan tentang perokok pasif

$x_{5}$ : Pengetahuan tentang perbedaan antara Perokok Pasif dan perokok Aktif

$x_{6}$ : Larangan merokok

$x_{7}$ : Intensitas melihat iklan rokok

$x_{8}$ : Komunikasi dengan orang tua

$x_{9}$ : Komunikasi dengan teman pergaulan

$x_{10}$ : Status merokok orang tua

$x_{11}$ : Usia responden

Tabel 1. Pemberian Peringkat Terhadap Pengetahuan Tentang Merokok

\begin{tabular}{|c|c|c|c|c|c|c|c|c|c|c|c|c|}
\hline Responden & $x_{1}$ & $x_{2}$ & $x_{3}$ & $x_{4}$ & $x_{5}$ & $x_{6}$ & $x_{7}$ & $x_{8}$ & $x_{9}$ & $x_{10}$ & $x_{11}$ & $x_{\text {total }}$ \\
\hline 1 & 5 & 5 & 5 & 1 & 1 & 5 & 5 & 5 & 5 & 5 & 4 & 42 \\
\hline 2 & 5 & 5 & 5 & 1 & 1 & 5 & 5 & 5 & 5 & 5 & 2 & 42 \\
\hline 3 & 5 & 5 & 5 & 5 & 1 & 5 & 5 & 3 & 5 & 5 & 5 & 44 \\
\hline 4 & 5 & 5 & 5 & 5 & 1 & 5 & 4 & 3 & 4 & 5 & 5 & 42 \\
\hline 5 & 5 & 5 & 5 & 5 & 1 & 5 & 4 & 3 & 5 & 1 & 4 & 39 \\
\hline 6 & 5 & 5 & 5 & 5 & 1 & 5 & 4 & 5 & 5 & 5 & 3 & 45 \\
\hline 7 & 5 & 5 & 5 & 5 & 1 & 5 & 3 & 5 & 5 & 5 & 4 & 44 \\
\hline 8 & 5 & 5 & 5 & 5 & 5 & 5 & 5 & 3 & 5 & 5 & 1 & 48 \\
\hline 9 & 5 & 5 & 5 & 5 & 5 & 5 & 5 & 3 & 5 & 5 & 1 & 48 \\
\hline 10 & 5 & 5 & 5 & 5 & 5 & 1 & 4 & 5 & 4 & 5 & 4 & 44 \\
\hline 11 & 5 & 5 & 5 & 5 & 1 & 5 & 5 & 3 & 5 & 5 & 3 & 44 \\
\hline 12 & 5 & 5 & 5 & 5 & 5 & 5 & 5 & 3 & 5 & 5 & 2 & 48 \\
\hline 13 & 1 & 5 & 5 & 5 & 5 & 5 & 5 & 5 & 4 & 5 & 5 & 45 \\
\hline 14 & 5 & 5 & 5 & 5 & 1 & 5 & 5 & 5 & 4 & 5 & 4 & 45 \\
\hline 15 & 5 & 5 & 5 & 5 & 1 & 5 & 5 & 5 & 4 & 1 & 2 & 41 \\
\hline 16 & 5 & 5 & 5 & 5 & 5 & 5 & 5 & 5 & 5 & 5 & 1 & 50 \\
\hline 17 & 5 & 5 & 5 & 5 & 5 & 5 & 5 & 5 & 4 & 1 & 3 & 45 \\
\hline 18 & 5 & 5 & 5 & 5 & 5 & 5 & 5 & 3 & 4 & 5 & 5 & 47 \\
\hline 19 & 5 & 5 & 5 & 5 & 1 & 1 & 4 & 3 & 4 & 5 & 2 & 38 \\
\hline 20 & 5 & 5 & 5 & 5 & 5 & 5 & 5 & 3 & 5 & 5 & 2 & 48 \\
\hline 21 & 5 & 5 & 5 & 5 & 5 & 5 & 5 & 3 & 5 & 5 & 3 & 48 \\
\hline 22 & 5 & 5 & 5 & 5 & 5 & 5 & 4 & 3 & 4 & 5 & 1 & 46 \\
\hline 23 & 5 & 5 & 5 & 5 & 5 & 1 & 5 & 3 & 5 & 5 & 1 & 44 \\
\hline 24 & 5 & 5 & 5 & 5 & 5 & 5 & 4 & 5 & 4 & 5 & 3 & 48 \\
\hline 25 & 5 & 5 & 5 & 5 & 5 & 5 & 5 & 5 & 5 & 1 & 5 & 46 \\
\hline 26 & 1 & 1 & 5 & 1 & 1 & 5 & 4 & 1 & 4 & 1 & 4 & 24 \\
\hline 27 & 5 & 5 & 5 & 5 & 5 & 5 & 5 & 3 & 5 & 5 & 2 & 48 \\
\hline 28 & 5 & 5 & 1 & 1 & 1 & 5 & 3 & 3 & 4 & 1 & 4 & 29 \\
\hline 29 & 1 & 1 & 4 & 1 & 4 & 4 & 4 & 3 & 4 & 5 & 3 & 31 \\
\hline 30 & 5 & 5 & 5 & 5 & 5 & 5 & 5 & 3 & 4 & 5 & 4 & 47 \\
\hline
\end{tabular}

Dari Tabel $1 \mathrm{di}$ atas dapat dilihat bahwa untuk responden pertama peringkat terendah ada pada $x_{4}$ dan $x_{5}$. Variabel lainnya memiliki peringat tertinggi yaitu 5.Ini menunjukkan bahwa responden pertama memiliki tingkat pengetahuan tentang merokok yang baik.

\subsection{Uji Kuesioner}

\section{a. Uji Validitas}

Sebelum kita menggunakan Regresi Logistik Ordinal maka terlebih dahulu akan diuji kelayakan kuesioner dengan menggunakan Uji Validitas. Validitas dapat diuji dengan cara melakukan korelasi bivariate antar masing-masing skor dengan total skor variable. Dengan melalui 11 pertanyaan yang menjadi indikator dari kepuasan $\left(x_{1}, x_{2}, x_{3}, \ldots, x_{11}\right)$, maka hal ini dapat dilakukan dengan membandingkan korelasi $x_{1}$ sampai dengan $x_{11}$ terhadap $x_{\text {total }}$. 
Prosedur:

\section{Analyze - correlate - bivariate}

2. Masukkan semua indikator dari $x_{1}, x_{2}, x_{3}, \ldots, x_{11}, x_{\text {total }}$. OK

3. Bila korelasi masing-masing indikator $x_{1}, x_{2}, x_{3}, \ldots, x_{11}$ terhadap $x_{\text {total }}$ menunjukkan hasil yang signifikan, maka dapat disimpulkan bahwa masing-masing indikator adalah valid. Kemudian dilanjutkan dengan uji reliabilitas.

Berdasarkan hasil analisis di atas didapat nilai korelasi antara $x_{1}, x_{2}, x_{3}, \ldots, x_{11}$ dan $x_{\text {total }}$. Jika nilai ini dibandingkan dengan nilai $r$ tabel, $r$ tabel dicari pada signifikansi 0,05 dengan uji 2 sisi dan jumlah data $(n)=30$, maka didapat $r$ tabel sebesar 0,3494.

Tabel 2. Correlations

\begin{tabular}{|c|c|c|c|c|c|c|c|c|c|c|c|c|c|}
\hline & & $x_{1}$ & $x_{2}$ & $x_{3}$ & $x_{4}$ & $x_{5}$ & $x_{6}$ & $x_{7}$ & $x_{8}$ & $x_{9}$ & $x_{10}$ & $x_{11}$ & Xtotal \\
\hline \multirow{3}{*}{$\mathrm{x} 1$} & Pearson Correlation & 1 & $.802^{* * *}$ & .076 & $.447^{*}$ & -.017 & -.028 & .126 & .224 & .356 & .111 & -.232 & $.566^{* *}$ \\
\hline & Sig. (2-tailed) & & .000 & .691 & .013 & .929 & .884 & .506 & .235 & .053 & .559 & .217 & .001 \\
\hline & $\mathrm{N}$ & 30 & 30 & 30 & 30 & 30 & 30 & 30 & 30 & 30 & 30 & 30 & 30 \\
\hline \multirow{3}{*}{$\mathrm{x} 2$} & Pearson Correlation & $.802^{* *}$ & 1 & .121 & $.598^{* * *}$ & .100 & .015 & .246 & $.424^{*}$ & .286 & .200 & -.086 & $.718^{* *}$ \\
\hline & Sig. (2-tailed) & .000 & & .523 & .000 & .599 & .938 & .190 & .020 & .126 & 288 & .650 & .000 \\
\hline & $\mathrm{N}$ & 30 & 30 & 30 & 30 & 30 & 30 & 30 & 30 & 30 & 30 & 30 & 30 \\
\hline \multirow{3}{*}{$\mathrm{x} 3$} & Pearson Correlation & .076 & .121 & 1 & $.508^{* *}$ & .189 & -.044 & $.504_{*}^{*}$ & .152 & .243 & .341 & -.124 & $.537^{* *}$ \\
\hline & Sig. (2-tailed) & .691 & .523 & & .004 & .317 & .817 & .005 & .422 & .196 & .066 & .513 & .002 \\
\hline & $\mathrm{N}$ & 30 & 30 & 30 & 30 & 30 & 30 & 30 & 30 & 30 & 30 & 30 & 30 \\
\hline \multirow{3}{*}{$\mathrm{x} 4$} & Pearson Correlation & $.447^{*}$ & $.598^{* * *}$ & $.508^{* *}$ & 1 & $.372^{*}$ & -.087 & .266 & .136 & .120 & .224 & -.111 & $.739^{* *}$ \\
\hline & Sig. (2-tailed) & .013 & .000 & .004 & & .043 & .648 & .155 & .473 & .529 & .235 & .558 & .000 \\
\hline & $\mathrm{N}$ & 30 & 30 & 30 & 30 & 30 & 30 & 30 & 30 & 30 & 30 & 30 & 30 \\
\hline \multirow{3}{*}{$\mathrm{x} 5$} & Pearson Correlation & -.017 & .100 & .189 & $.372^{*}$ & 1 & -.084 & $.388^{*}$ & -.018 & .009 & .229 & -.310 & $.547^{* *}$ \\
\hline & Sig. (2-tailed) & .929 & .599 & .317 & .043 & & .658 & .034 & .926 & .962 & .223 & .095 & .002 \\
\hline & $\mathrm{N}$ & 30 & 30 & 30 & 30 & 30 & 30 & 30 & 30 & 30 & 30 & 30 & 30 \\
\hline \multirow{3}{*}{ x6 } & Pearson Correlation & -.028 & .015 & -.044 & -.087 & -.084 & 1 & .152 & .039 & .163 & -.180 & .183 & .133 \\
\hline & Sig. (2-tailed) & .884 & .938 & .817 & .648 & .658 & & .424 & .838 & .389 & .341 & .332 & .482 \\
\hline & $\mathrm{N}$ & 30 & 30 & 30 & 30 & 30 & 30 & 30 & 30 & 30 & 30 & 30 & 30 \\
\hline \multirow{3}{*}{$\mathrm{x} 7$} & Pearson Correlation & .126 & .246 & $.504^{* *}$ & .266 & $.388^{*}$ & .152 & 1 & .076 & .318 & .190 & -.207 & $.555^{* *}$ \\
\hline & Sig. (2-tailed) & .506 & .190 & .005 & .155 & .034 & .424 & & .690 & .086 & .316 & .271 & .001 \\
\hline & $\mathrm{N}$ & 30 & 30 & 30 & 30 & 30 & 30 & 30 & 30 & 30 & 30 & 30 & 30 \\
\hline \multirow{3}{*}{$\mathrm{x} 8$} & Pearson Correlation & .224 & $.424^{*}$ & .152 & .136 & -.018 & .039 & .076 & 1 & .016 & .030 & .103 & $.376^{*}$ \\
\hline & Sig. (2-tailed) & .235 & .020 & .422 & .473 & .926 & .838 & .690 & & .932 & .873 & .588 & .041 \\
\hline & $\mathrm{N}$ & 30 & 30 & 30 & 30 & 30 & 30 & 30 & 30 & 30 & 30 & 30 & 30 \\
\hline \multirow{3}{*}{ x9 } & Pearson Correlation & .356 & .286 & .243 & .120 & .009 & .163 & .318 & .016 & 1 & .200 & -.303 & $.393^{*}$ \\
\hline & Sig. (2-tailed) & .053 & .126 & .196 & .529 & .962 & .389 & .086 & .932 & & .288 & .104 & .032 \\
\hline & $\mathrm{N}$ & 30 & 30 & 30 & 30 & 30 & 30 & 30 & 30 & 30 & 30 & 30 & 30 \\
\hline \multirow{3}{*}{$\mathrm{x} 10$} & Pearson Correlation & .111 & .200 & .341 & .224 & .229 & -.180 & .190 & .030 & .200 & 1 & -.224 & $.509^{* *}$ \\
\hline & Sig. (2-tailed) & .559 & .288 & .066 & .235 & .223 & .341 & .316 & .873 & .288 & & .234 & .004 \\
\hline & $\mathrm{N}$ & 30 & 30 & 30 & 30 & 30 & 30 & 30 & 30 & 30 & 30 & 30 & 30 \\
\hline \multirow{3}{*}{ x11 } & Pearson Correlation & -.232 & -.086 & -.124 & -.111 & -.310 & .183 & -.207 & .103 & -.303 & -.224 & 1 & -.260 \\
\hline & Sig. (2-tailed) & .217 & .650 & .513 & .558 & .095 & .332 & .271 & .588 & .104 & .234 & & .165 \\
\hline & $\mathrm{N}$ & 30 & 30 & 30 & 30 & 30 & 30 & 30 & 30 & 30 & 30 & 30 & 30 \\
\hline \multirow{3}{*}{ Xtotal } & Pearson Correlation & $.566^{* *}$ & $.718^{* *}$ & $.537^{* *}$ & $.739^{* *}$ & $.547^{* *}$ & .133 & $.555^{*}$ & $.376^{*}$ & $.393^{*}$ & $.509^{*}$ & -.260 & 1 \\
\hline & Sig. (2-tailed) & .001 & .000 & .002 & .000 & .002 & .482 & .001 & .041 & .032 & .004 & .165 & \\
\hline & $\mathrm{N}$ & 30 & 30 & 30 & 30 & 30 & 30 & 30 & 30 & 30 & 30 & 30 & 30 \\
\hline
\end{tabular}

**. Correlation is significant at the 0.01 level (2-tailed).

*. Correlation is significant at the 0.05 level (2-tailed). 
Berdasarkan hasil analisis di atas didapat nilai korelasi untuk $x_{6}, x_{11}$ kurang dari 0,3494 . Karena koefisen korelasi pada $x_{6}$ dan $x_{11}$ nilainya kurang dari 0,3494 maka dapat disimpulkan bahwa $x_{6}, x_{11}$ tidak berkorelasi signifikan dengan skor total (dinyatakan tidak valid).

\section{b. Uji Reliabilitas}

Setelah menggunakan uji validitas maka akan diuji kembali dengan menggunakan Uji Reliabilitas. Setelah diuji didapatkan hasil sebagai berikut.

Tabel 3. Item-Total Statistics

\begin{tabular}{|c|c|c|c|c|}
\hline & $\begin{array}{c}\text { Scale Mean if Item } \\
\text { Deleted }\end{array}$ & $\begin{array}{c}\text { Scale Variance if } \\
\text { Item Deleted }\end{array}$ & $\begin{array}{c}\text { Corrected Item-Total } \\
\text { Correlation }\end{array}$ & $\begin{array}{c}\text { Cronbach's Alpha if } \\
\text { Item Deleted }\end{array}$ \\
\hline x1 & 85.13 & 122.602 & .474 & .637 \\
x2 & 85.00 & 120.690 & .680 & .625 \\
x3 & 84.90 & 128.093 & .488 & .649 \\
x4 & 85.40 & 112.800 & .677 & .604 \\
x5 & 86.50 & 116.397 & .384 & .636 \\
x6 & 85.17 & 133.868 & .054 & .676 \\
x7 & 85.17 & 129.316 & .505 & .651 \\
x8 & 86.00 & 127.793 & .313 & .653 \\
x9 & 85.20 & 132.786 & .329 & .662 \\
x10 & 85.53 & 120.671 & .380 & .640 \\
x11 & 86.67 & 143.540 & -.260 & .707 \\
Xtotal & 46.40 & 33.490 & .974 & .534 \\
\hline
\end{tabular}

Dari output di atas bisa dilihat pada Corrected Item - Total Correlation. Nilai ini kemudian kita bandingkan dengan $r$ tabel, $r$ tabel dicari pada signifikan 0,05 dengan uji 2 sisi dan jumlah data $(n)=12$, maka didapat $r$ tabel sebesar 0,3494 (dilihat pada lampiran tabel $r$ ).

Dari hasil analisis dapat dilihat bahwa untuk $x_{6}, x_{8}, x_{9}$, dan $x_{11}$ kurang dari 0,3494. Karena koefisien korelasi pada $x_{6}, x_{8}, x_{9}$, dan $x_{11}$ nilainya kurang dari 0,3494 maka kita uji kembali dan mengeluarkan $x_{6}, x_{8}, x_{9}$, dan $x_{11}$. Setelah dilakukan uji ulang hasilnya sebagai berikut:

Tabel 4. Item-Total Statistics

\begin{tabular}{|c|c|c|c|c|}
\hline & $\begin{array}{c}\text { Scale Mean if Item } \\
\text { Deleted }\end{array}$ & $\begin{array}{c}\text { Scale Variance if } \\
\text { Item Deleted }\end{array}$ & $\begin{array}{c}\text { Corrected Item-Total } \\
\text { Correlation }\end{array}$ & $\begin{array}{c}\text { Cronbach's Alpha if } \\
\text { Item Deleted }\end{array}$ \\
\hline $\mathrm{x} 1$ & 69.23 & 114.047 & .484 & .688 \\
$\mathrm{x} 2$ & 69.10 & 112.990 & .655 & .679 \\
$\mathrm{x} 3$ & 69.00 & 119.448 & .499 & .701 \\
$\mathrm{x} 4$ & 69.50 & 103.914 & .709 & .650 \\
$\mathrm{x} 5$ & 70.60 & 105.490 & .456 & .677 \\
$\mathrm{x} 7$ & 69.27 & 120.754 & .509 & .704 \\
$\mathrm{x} 10$ & 69.63 & 110.654 & .433 & .686 \\
Xtotal & 30.50 & 29.845 & .954 & .682 \\
\hline
\end{tabular}

Dari output di atas, dapat kita simpulkan bahwa $x_{1}, x_{2}, x_{3}, x_{4}, x_{5}, x_{7}$ dan $x_{10}$ valid. 


\subsection{Regresi Logistik Ordinal}

Berdasarkan data pada tabel di atas, dengan menggunakan software SPSS, hasil pengujiannya diperoleh nilai signifikansi $(p$-value $)=0.000$ karena $p$-value $<\alpha$. Maka kesimpulannya adalah terdapat minimal ada satu variable bebas yang berpengaruh terhadap tingkat pengetahuan remaja tentang perilaku merokok (tolak $\left.H_{0}\right)$.

\section{Hipotesis:}

$H_{0}: \beta_{1}=\beta_{2}=\cdots=\beta_{j}=0$

$H_{1}$ : Minimal ada satu $\beta_{j} \neq 0, j=1,2, \cdots, p$

Statistik uji:

$$
G=-2 \log \left[\frac{\left(\frac{n_{0}}{n}\right)^{n_{0}}\left(\frac{n_{1}}{n}\right)^{n_{1}}\left(\frac{n_{2}}{n}\right)^{n_{2}}}{\prod_{i=1}^{n}\left[\phi_{o}\left(x_{i}\right)^{y_{0 i}} \phi_{1}\left(x_{i}\right)^{y_{1 i}} \phi_{2}\left(x_{i}\right)^{\left.y_{2 i}\right]}\right.}\right]
$$

dimana, $n_{0}=\sum_{i=1}^{n} y_{0 i}, n_{1}=\sum_{i=1}^{n} y_{1 i}, n_{2}=\sum_{i=1}^{n} y_{2 i}$,

dan $\mathrm{n}=n_{0}+n_{1}+n_{2}$.

Keterangan :

$n_{0}$ : banyaknya nilai observasi yang $Y=0$

$n_{1}$ : banyaknya nilai observasi yang $Y=1$

$n_{2}$ : banyaknya nilai observasi yang $Y=2$

$n$ : banyaknya observasi

$H_{0}$ ditolak pada tingkat signifikan sebesar $\alpha$ bila nilai $p$-value $<\alpha$ atau nilai $G>X^{2}{ }_{\alpha, d b}$

Dengan nilai Pseudo $R 2$ sebesar 1. Pada pengujian parsial terlihat bahwa terdapat tujuh variabel bebas yang berpengaruh secara signifikan ( $p$-value $<0.05$ ), yaitu $x_{1}, x_{4}, x_{5}, x_{6}, x_{8}, x_{9}$, dan $x_{10}$.

Tabel 5. Pseudo R-Square

\begin{tabular}{|l|r|}
\hline Cox and Snell & .990 \\
Nagelkerke & 1.000 \\
McFadden & 1.000 \\
\hline
\end{tabular}

Link function: Logit.

Odds Ratio, $x_{10}$ (status merokok orang tua) $=2.2$, artinya remaja yang orang tuanya tidak perokok cenderung memiliki tingkat pengetahuan yang lebih tinggi 2.2 kali dari pada remaja yang orang tuanya perokok. Odds Ratio, $x_{4}$ (kerugian merokok) $=0.333$, artinya remaja yang mengetahui tentang kerugian merokok cenderung memiliki tingkat pengetahuan yang lebih tinggi 0.333 kali dari pada remaja yang tidak mengetahui tentang kerugian merokok. 
Tabel 6. Parameter Estimates

\begin{tabular}{|c|c|c|c|c|c|c|c|c|}
\hline & & Estimate & Std. Error & Wald & $\mathrm{df}$ & Sig. & $95 \%$ Confid & nce Interval \\
\hline & & & & & & & Lower Bound & Upper Bound \\
\hline & {$[\mathrm{x} 1=1]$} & -13.334 & 4.419 & 9.104 & 1 & .003 & -21.996 & -4.673 \\
\hline & {$[\mathrm{x} 1=5]$} & $0^{\mathrm{a}}$ & & . & 0 & & & \\
\hline & {$[\mathrm{x} 2=1]$} & 9.501 & 13.097 & .526 & 1 & .468 & -16.167 & 35.170 \\
\hline & {$[\times 2=5]$} & $0^{\mathrm{a}}$ & & . & 0 & . & & \\
\hline & {$[\mathrm{x} 3=1]$} & 15.909 & 9.448 & 2.835 & 1 & .092 & -2.609 & 34.427 \\
\hline & {$[\mathrm{x} 3=4]$} & -12.201 & 12.110 & 1.015 & 1 & .314 & -35.937 & 11.534 \\
\hline & {$[\mathrm{x} 3=5]$} & $0^{\mathrm{a}}$ & & . & 0 & & & \\
\hline & {$[\mathrm{x} 4=1]$} & -14.762 & 4.605 & 10.275 & 1 & .001 & -23.788 & -5.736 \\
\hline & {$[\mathrm{x} 4=5]$} & $0^{\mathrm{a}}$ & & . & 0 & & & \\
\hline & {$[\times 5=1]$} & -14.895 & 3.599 & 17.133 & 1 & .000 & -21.948 & -7.842 \\
\hline & {$[\times 5=4]$} & $0^{\mathrm{a}}$ & & & 0 & & & \\
\hline & {$[\mathrm{x} 5=5]$} & $0^{\mathrm{a}}$ & . & . & 0 & & & \\
\hline & {$[\times 6=1]$} & -15.162 & 3.810 & 15.836 & 1 & & -22.629 & -7.694 \\
\hline & {$[\times 6=4]$} & $0^{\mathrm{a}}$ & & . & 0 & & & \\
\hline & {$[\times 6=5]$} & $0^{\mathrm{a}}$ & . & . & 0 & . & & \\
\hline Lutativin & {$[\times 7=3]$} & -8.556 & 4.638 & 3.404 & 1 & .065 & -17.646 & .533 \\
\hline & {$[\times 7=4]$} & -2.524 & 1.762 & 2.053 & 1 & .152 & -5.978 & .929 \\
\hline & {$[\mathrm{x} 7=5]$} & $0^{\mathrm{a}}$ & . & . & 0 & & & \\
\hline & {$[\mathrm{x} 8=1]$} & $0^{\mathrm{a}}$ & & . & 0 & & & \\
\hline & {$[\mathrm{x} 8=3]$} & -7.195 & 2.264 & 10.100 & 1 & 001 & -11.633 & -2.758 \\
\hline & {$[\mathrm{x} 8=5]$} & $0^{\mathrm{a}}$ & . & . & 0 & & & \\
\hline & {$[\times 9=4]$} & -4.248 & 1.671 & 6.461 & 1 & .011 & -7.523 & -.972 \\
\hline & {$[\mathrm{x} 9=5]$} & $0^{\mathrm{a}}$ & & . & 0 & & & \\
\hline & {$[\mathrm{x} 10=1]$} & -14.228 & 3.645 & 15.239 & 1 & & -21.371 & -7.085 \\
\hline & {$[\times 10=5]$} & $0^{\mathrm{a}}$ & & . & 0 & & & \\
\hline & {$[\mathrm{x} 11=1]$} & .269 & 2.052 & .017 & 1 & .896 & -3.753 & 4.290 \\
\hline & {$[\mathrm{x} 11=2]$} & 1.036 & 2.380 & .189 & 1 & .663 & -3.629 & 5.701 \\
\hline & {$[x 11=3]$} & .222 & 2.025 & .012 & 1 & .913 & -3.747 & 4.191 \\
\hline & {$[\mathrm{x} 11=4]$} & .466 & 1.929 & .058 & 1 & .809 & -3.314 & 4.246 \\
\hline & {$[\mathrm{x} 11=5]$} & $0^{\mathrm{a}}$ & & & 0 & & & \\
\hline
\end{tabular}

Link function: Logit.

a. This parameter is set to zero because it is redundant. 


\section{Kesimpulan}

Variabel yang berpengaruh signifikan terhadap tingkat pengetahuan remaja tentang perilaku merokok adalah variabel $x_{1}, x_{4}, x_{4}, x_{6}, x_{8}, x_{9}, x_{10}$. Dapat dilihat juga variabel yang paling dominan memengaruhi tingkat pengetahuan remaja tentang perilaku merokok adalah variabel $x_{10}$ (status merokok orang tua).

\section{Daftar Pustaka}

[1] B. Smet, Psikologi Kesehatan, Semarang: PT. Gramedia Pustaka Utama, 1994.

[2] M. Armstrong, Manajemen Sumber Daya Manusia, Jakarta: PT. Gramedia Pustaka Utama, 1990.

[3] H. Danusanto, Rokok dan Perokok, Jakarta: Aksara, 1991.

[4] I. B. Januartha, e-Jurnal Matematika, vol. I, no. 1, 2012.

[5] Z. Mu'tadin, Kemandirian sebagai Kebutuhan Psikologi pada Remaja, 2002.

[6] A. Parrot, "Does Cigarette Smoking Cause Stress?," Journal of Clinican Psycology, 2004.

[7] W. J. S. Poerwadarminta, Kamus Umum Bahasa Indonesia, Jakarta: Balai Pustaka, 1995.

[8] Siquera, "Smoking Cessation in Adolescents: The Role of Nicotine Dependence, Stress, and Copying.," Chicago, 2004. 